\title{
COMUNICAÇÃO ORONASAL E EXPOSIÇÃO ÓSSEA POR DOENÇA PERIODONTAL E LESÃO REABSORTIVA DENTÁRIA EM UM GATO - RELATO DE CASO
}

(Oronasal communication and bone exposure for periodontal disease and resorptive lesion in a cat - case report)

Helena Baggio Soares, Rogério Ribas Lange, Dejoara de Angelis Zvoboda, Marcos Vinicius Almeida Moraes

Universidade Federal do Paraná, Curitiba, Paraná, Brasil.

*Correspondência: mvhelenabaggio@gmail.com

RESUMO: Doenças orais em gatos são de elevada prevalência. No entanto, mesmo diante da grande incidência, tais afecções ainda são subdiagnosticadas. As principais enfermidades orais nessa espécie são a lesão de reabsorção dentária, a doença periodontal e fraturas dentárias. Essas alterações frequentemente causam dor oral, podendo desencadear inapetência e anorexia. Um gato, sem raça definida, 15 anos, castrado, foi atendido no Hospital Veterinário com histórico de inapetência, perda de peso progressiva e prostração há mais de 30 dias. Na avaliação física, constatou-se que o paciente fazia movimentos repetitivos de abrir e fechar a boca, apresentava halitose, sialorreia e dor em cavidade oral. $\mathrm{Na}$ avaliação odontológica sob anestesia geral foi observada importante exposição dos ossos incisivo, maxilar e palatino esquerdos com sinais de invasão do osso palatino direito. Também havia comunicação oronasal e cálculo dentário em grande quantidade, mobilidade dentária, retração gengival e bolsa periodontal. Nas imagens radiográficas intra-orais documentou-se alteração óssea em região de caninos superiores esquerdo (204) e direito (104) e perda de definição de ligamento periodontal em incisivos, caninos e molares superiores (anquilose). O dente 204 apresentava sinal de reabsorção dentária grave em raiz, perda de osso alveolar, fratura com exposição de polpa e alteração de coloração. O pré-molar superior esquerdo (206) apresentou reabsorção em coroa. Os inferiores apresentaram anquilose grave e reabsorção dentária do dente pré-molar inferior esquerdo (307). Os achados permitiram diagnosticar doença periodontal (DPO), lesão reabsortiva dentária felina (LRDF), fratura dentária e exposição óssea dos ossos incisivo, maxilar e palatino esquerdos. Dada a grave evolução do problema, concluiu-se que nenhum tratamento odontológico poderia melhorar os sinais clínicos, tampouco a qualidade de vida do paciente. Destarte, o proprietário optou pela eutanásia. Este relato evidencia o potencial de evolução negativo das afecções da cavidade oral quando não diagnosticadas e tratadas precocemente.

Palavras-chave: doenças orais; dor oral; reabsorção dentária 